\title{
PENGUKURAN INTENSITAS DAN PENETRASI CAHAYA LAMPU LED ( $L I G H T$ EMITTING DIODE) BAWAH AIR DAN TL (TUBULAR LAMP) PADA BAGAN RAKIT
}

\author{
Measurement of Intensity and Penetration of Light Underwater and TL (Turbular Lamp) LED (Light \\ Emitting Diode) Lamp in Floating Bagan
}

Oleh:

\author{
Ronny I Wahju ${ }^{1}$, M. Riyanto ${ }^{1}$, Suparman Sasmita ${ }^{2}$, Ressa S Syahlevi ${ }^{1}$ dan Fis \\ Purwangka ${ }^{1}$ \\ ${ }^{1}$ Departemen Pemanfaatan Sumberdaya Perikanan, FPIK-IPB \\ ${ }^{2}$ Balai Besar Penangkapan Ikan Semarang, KKP \\ Korespondensi: rwahyu06@gmail.com
}

\begin{abstract}
ABSTRAK
Penelitian pengukuran sebaran intensitas pada lampu TL dan lampu LED bawah air pada bagan rakit telah dilakukan di perairan Palabuhanratu. Tujuan penelitian mengukur iluminasi dan sebaran cahaya lampu LED 60 watt, TL 390 dan 585 watt serta mengidentifikasi hasil tangkapan. Metode yang digunakan dalam penelitian ini adalah survei dengan mengikuti kegiatan langsung operasi penangkapan ikan. Hasil penelitian menunjukkan bahwa penetrasi cahaya lampu LED 60 watt mampu menembus perairan hingga kedalaman 9 meter. Nilai tertinggi terdapat pada titik 0 , kedalaman 1 meter dengan nilai 2,5x10-4 watt $/ \mathrm{cm}^{2}$ dan titik terendah terdapat pada titik 1 pada kedalaman 9 meter dengan nilai 3E-005 watt $/ \mathrm{cm}^{2}$. Penetrasi cahaya kedua lampu TL yaitu TL 390 dan 585 watt hanya mampu menembus air hingga kedalaman 3-4 meter. Pengukuran lampu TL 390 watt didapatkan nilai tertinggi pada titik 0 di kedalaman 0 meter dengan nilai 0,358 watt $/ \mathrm{cm}^{2}$. Pengukuran lampu TL 585 watt didapatkan nilai tertinggi pada titik 0 di kedalaman 1 meter dengan nilai $0.819 \mathrm{watt} / \mathrm{cm}^{2}$. Hasil tangkapan LED didominasi oleh ikan petek sebesar 94\%, lampu TL 390 dan TL 585 watt didominasi ikan teri (Stolephorus sp) sebesar 55\% dan 49\%.
\end{abstract}

Kata kunci: bagan rakit, lampu LED, lampu TL

\begin{abstract}
Research on measuring the intensity distribution of TL lamps and underwater LED lights on bagan carried out in Pelabuhanratu waters. The purpose of the study was to measure the illumination and the light distribution of 60 watt LED lights, TL 390 and 585 watts and to identify the catch. The method used in this study is a survey method. The results showed that the light penetration of a 60 watt LED lamp was able to penetrate the waters to a depth of 9 meters. The highest value found at point 1 depth of 1 meter with a value of 2.5x10-4 watt / cm2 and the lowest point is at point 1 at a depth of 9 meters with a value of $3 E-005$ watts / cm 2. The light penetration of both TL lamps, TL 390 and 585 watts, is only able to penetrate water to a depth of 3-4 meters. TL 390 watt lamp measurements obtained the highest value at point $O$ at a depth of $O$ meters with a value of 0.358 watt $/ \mathrm{cm} 2$. The measurement of TL 585 watt lights obtained the highest value at point $O$ at a depth of 1 meter with a value of 0.819 watts/cm2. The catch of LED was dominated by petek $94 \%$ (Leiognathus dussumieri) while TL 390 lights and TL 585 was dominated by teri (Stolephorus sp.) 55\% and 49\% respectively.
\end{abstract}

Key words: lifnet, LED lamp, TL lamp 


\section{PENDAHULUAN}

Pemanfaatan lampu sebagai alat bantu penangkapan ikan telah berkembang sejak ditemukannya listrik dengan tujuan untuk menarik ikan-ikan yang mempunyai sifat fototaksis positif (BBPPI 2007; Hasan 2008). Bagan merupakan alat penangkapan ikan yang menggunakan lampu sebagai alat bantu penangkapan ikan. Permasalahan yang dihadapi dalam menggunakan alat bantu lampu, diantaranya penggunaan lampu yang belum efisien. Jenis lampu yang banyak digunakan nelayan yaitu lampu Turbular Lamps (TL). Namun demikian produktivitas bagan dalam menggunakan lampu TL relatif masih rendah (Saffrie 2012). Penelitian yang telah dilakukan menunjukkan dalam penggunaan lampu untuk penangkapan ikan beberapa faktor teknis yang berpengaruh. Faktor tersebut diantaranya reflektor, kondisi lampu serta intensitas cahaya lampu yang berbeda akan mempengaruhi keberadaan ikan disekitar lampu (Puspito 2008; Patty 2010;Puspito 2012; Ahmad et al., 2013). Selain itu lampu TL hanya memiliki umur teknis 60.000 jam dengan pemakaian rata-rata 3 jam (Taufiq 2015). Biaya operasional lampu TL cukup tinggi dan kurang optimalnya sebagai alat bantu penangkapan ikan, khususnya pada perikanan bagan (Setiawan et al. 2015).

Penggunaan lampu LED atau Light Emitting Diode bawah air merupakan salah satu alternatif yang dapat digunakan pada alat tangkap bagan. Lampu LED memiliki umur teknis yang lebih lama hingga 80.000 dengan cahaya yang lebih terang, efisien dan murah (Taufiq 2015). Perbedaan intensitas iluminasi dan sebaran cahaya dari turbular lamp dan LED berdasarkan hasil tangkapan pada bagan dapat dijadikan alternatif untuk mengurangi penggunaan bahan bakar dan efisiensi biaya (Suuronen et al. (2012).

Penelitian yang berkaitan dengan penangkapan ikan yang menggunakan lampu LED ( Light Emitting Diode) telah dilakukan, diantaranya untuk respon tingkah laku ikan (Haruna 2010; Rifaldi 2016), pengukuran sebaran intensitas cahaya (Julian 2014). Sementara pada lampu turbular lamp (TL), penelitian pengukuran sebaran cahaya dalam air serta efektivitas lampu TL telah dilakukan (Holil 2000). Namun demikian pengukuran pengukuran iluminasi dan sebaran cahaya dengan LED dengan intensitas berbeda belum dilakukan. Hal ini merupakan informasi yang penting dalam pengembangan alat bantu penangkapan ikan. Tujuan penelitian ini adalah mengestimasi iluminasi dan sebaran cahaya dengan lampu LED 60 watt, TL 390 watt dan TL 585 watt, 2) dan mengindentifikasi hasil tangkapan dari lampu LED 60 watt, TL 390 watt dan TL 585 watt.

\section{METODE PENELITIAN}

Pelaksanaan penelitian dilakukan pada Januari - Februari 2016. Pengambilan data lapang dilakukan di PPN Palabuhan Ratu, Sukabumi, Jawa Barat. Secara geografis lokasi pengoperasian penangkapan ikan, di beberapa titik dari koordinat antara 659'02.24"S hingga 6 ${ }^{\circ} 59^{\prime} 29.57 " S$ dan $106^{\circ} 31^{\prime} 52.48^{\prime \prime} \mathrm{E}$ hingga $106^{\circ} 31^{\prime} 54.14^{\prime \prime} \mathrm{E}$.

Alat yang digunakan pada penelitian ini adalah : Lux Meter Krisbow kw06-288 digunakan untuk mengukur intensitas cahaya, Global Positioning System (GPS), Fish Finder 250 sebagai alat untuk mengetahui keberadaan ikan dan International Light Technologies 5000 untuk mengukur intensitas cahaya di dalam air. Bahan yang digunakan pada penelitian ini adalah: bagan rakit berukuran 8x8 m, Lampu LED bawah air berjumlah 1 buah dengan daya 60 watt setara dengan daya lampu TL 390 watt dan 585 watt. Lampu TL berjumlah 6 buah (390 watt) dengan masing-masing daya lampu 65 watt. Lampu TL berjumlah 9 buah (585 watt) dengan masing-masing daya lampu 65 watt.

Penelitian dilakukan dengan menggunakan metode survei. Jenis data yang dikumpulkan dalam penelitian ini adalah data primer dengan mengikuti operasi penangkapan ikan di bagan rakit dan observasi di lapang. Data primer yang di peroleh meliputi data intensitas cahaya lampu LED 60 watt, TL 390 watt dan TL 585 watt serta data komposisi hasil tangkapan. Data yang dikumpulkan berupa intensitas cahaya yang berada di udara dan di air laut. Total 9 trip telah dilakukan dengan rincian 7 trip 
menggunakan lampu LED 60 watt, satu trip menggunakan lampu TL 390 watt, dan satu trip lainnya menggunakan lampu TL 585 watt. Pengambilan data di bagan dilakukan pada antara jam 18.00 sampai jam 04.30.

\section{Pengukuran Iluminasi dan Sebaran Cahaya Lampu LED 60 watt di Laboratoium}

Pengambilan data intensitas cahaya pada medium udara dilakukan secara langsung di laboraturium dengan metode pengukuran busur. Titik pengukuran berbentuk busur setengah lingkaran $180^{\circ}$, dimulai dari titik 00 hingga 1800. Pengukuran dilakukan sesuai posisi titik pada busur dengan jarak ukur 1m. Posisi pengukuran dapat dilihat pada Gambar 1.

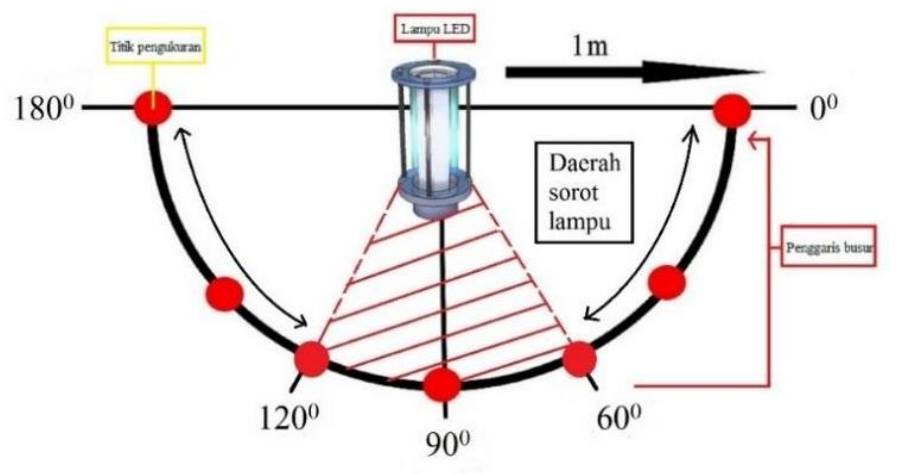

Gambar 1 Pengambilan data intensitas cahaya di laboratorium.

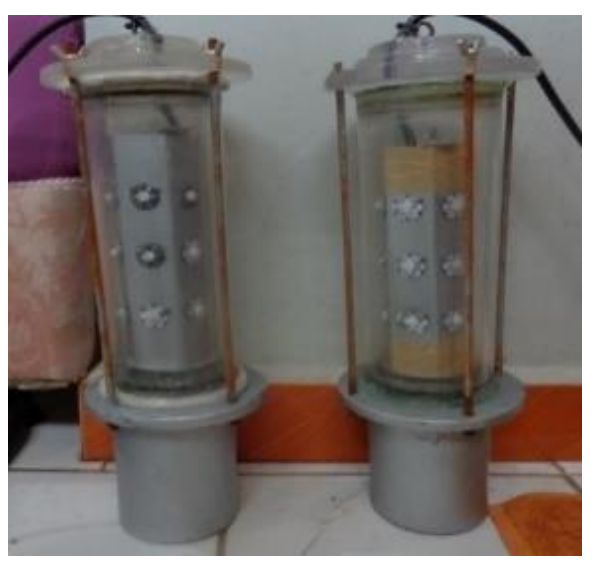

Pengukuran Iluminasi dan Sebaran Cahaya Vertikal Lampu LED 60 watt, TL 390 watt, serta 585 watt di Lapangan

Posisi lampu LED dan TL diletakkan di tengah-tengah bagan rakit. Posisi lampu LED berada di kedalaman antara 1 sampai 2 meter, sedangkan TL berada 1 meter di atas permukaan air. Pengambilan data sebaran cahaya dihitung ke arah vertikal dan horizontal dengan jarak pengukuran per 1 meter. Arah horizontal di ukur sampai jarak 2 meter ke samping kanan dan 2 meter ke samping kiri. Arah vertikal dihitung sampai kedalaman 13 meter. Sementara pada lampu TL pengambilan data sebaran cahaya pada permukaan perairan di titik 0 yang berada tepat di bawah lampu. Pengukuran dilakukan ke arah vertikal dan horizontal dengan jarak 1 meter seperti pada Gambar 2.

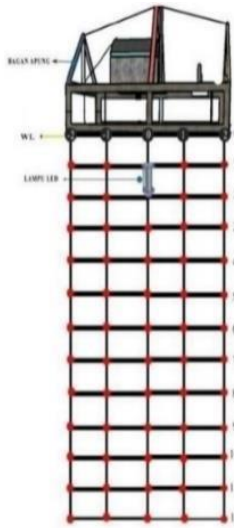

LED

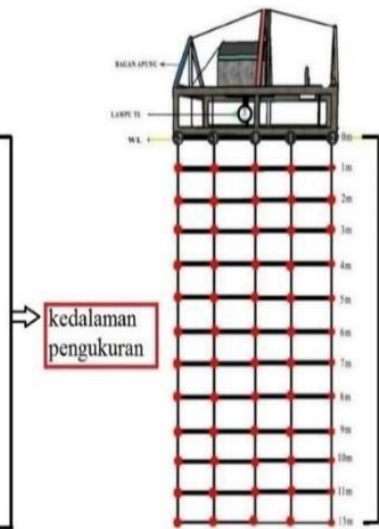

$\mathrm{TL}$

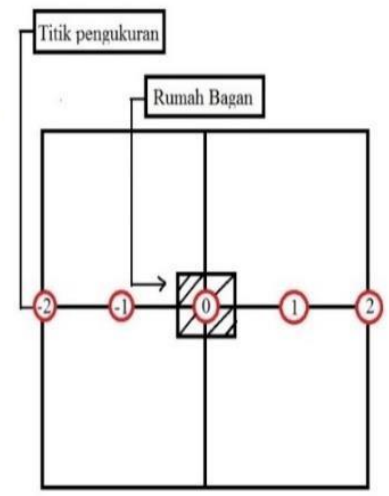

Bagan tampak atas

Gambar 2 Pengukuran intensitas cahaya LED dan TL.

Data sebaran intensitas cahaya ditabulasi dalam satuan watt $/ \mathrm{cm}^{2}$. Data sebaran intensitas cahaya disajikan dalam bentuk tabel dan selanjutnya akan dideskripsikan untuk mencapai tujuan penelitian 
ini. Tabel tersebut berisi hari, tanggal, setting, hauling, jenis, serta berat ikan dari hasil tangkapan dalam satuan kg selama pengoperasian bagan rakit kemudian data diolah menggunakan aplikasi Surfer 10 (32-bit). Data iluminasi cahaya lampu LED dan TL yang disajikan berupa grafik dan gambar. Selanjutnya hasil olahan data untuk lampu LED dan TL, serta hasil tangkapan dianalisis secara deskriptif.

\section{HASIL DAN PEMBAHASAN}

\section{Iluminasi dan Sebaran Cahaya Lampu LED 60 watt di Laboratorium}

Hasil dari pengukuran iluminasi cahaya lampu LED di udara pada sisi sudut $0^{0}-60^{\circ}$ berkisar antara $0,36 \times 10^{-4}-4,3 \times 10^{-4}$ watt $/ \mathrm{cm}^{2}$ dan sudut $100^{0}-180^{\circ}$ berkisar antara $0,0001795-0,00038948$ watt $/ \mathrm{cm}^{2}$. Nilai iluminasi tertinggi pada sudut busur $20^{\circ}$ dengan nilai $5,5 \times 10^{-4} \mathrm{watt} / \mathrm{cm}^{2}$ dan nilai iluminasi terendah pada sudut busur $70^{\circ}, 80^{\circ}, 90^{\circ}$ dengan nilai 0 watt $/ \mathrm{cm}^{2}$. Nilai iluminasi cahaya dapat di lihat pada Gambar 3.

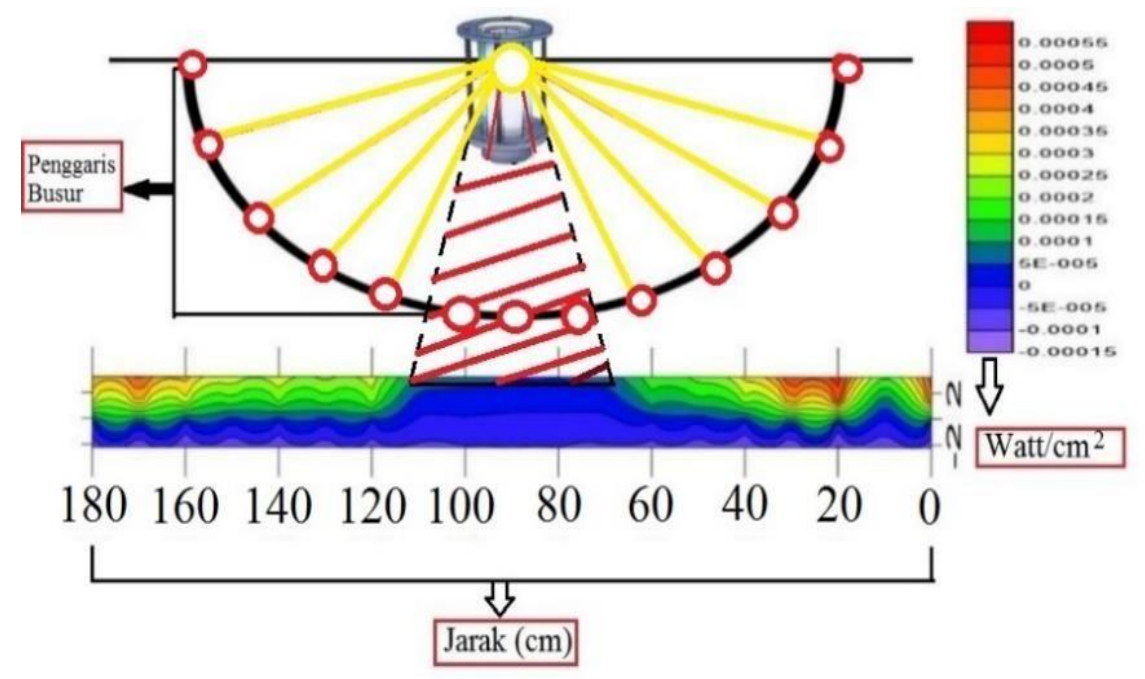

Gambar 3 Distribusi intensitas cahaya lampu LED 60 watt di laboratorium.

Hasil pengukuran nilai iluminasi cahaya pada lampu LED di udara lebih besar dari nilai iluminasi LED di air laut, seperti pada Gambar 3 nilai iluminasi cahaya LED di air laut 2,59x10-4 watt $/ \mathrm{cm}^{2}$ sedangkan nilai di udara $5,5 \times 10^{-4} \mathrm{watt} / \mathrm{cm}^{2}$. Hal ini disebabkan oleh medium udara yang kerapatannya lebih rendah dibandingkan medium air. Frekuensi cahaya tidak mengalami perubahan saat merambat di udara, hanya cepat rambat dan panjangnya yang berubah (Syafrie 2012). Cahaya yang merambat dari medium udara ke air akan mengalami penurunan iluminasi. Hasil pengukuran iluminasi cahaya pada medium udara tidak menunjukkan perbedaan yang signifikan pada setiap sudut pengamatan. Hal ini karena pengaruh lampu yang berbentuk tabung (Taufiq (2015).

\section{Iluminasi dan Sebaran Cahaya Lampu LED 60 watt di dalam Laut}

Berdasarkan data iluminasi cahaya dari hasil pengukuran lampu LED 60 watt sampai kedalaman $13 \mathrm{~m}$ dapat dilihat pada tabel 1 . Nilai iluminasi tertinggi pada titik 0 sampai kedalaman 1 meter yaitu $2,59 \times 10^{-4} \mathrm{watt} / \mathrm{cm}^{2}$. Titik 2 kedalaman 13 meter merupakan nilai terendah dikarenakan posisi tersebut jauh dari cahaya lampu LED yaitu 0,003 x $10^{-4}$ dengan kecerahan air laut 7-10 meter. Iluminasi cahaya lampu LED 60 watt di bagan rakit yang sudah diolah menggunakan aplikasi surfer 10 (32-bit) kecerahan cahaya terlihat sampai kedalaman 9 meter. Pada titik 1 dengan nilai sebesar $0,01 \times 10^{-4} \mathrm{watt} / \mathrm{cm}^{2}$. Pada titik 0 kedalaman 1 meter terlihat bahwa warna merah yang mencolok pada grafik tersebut merupakan titik cahaya yang paling terang, dengan nilai iluminasi tertinggi sebesar $2,59 \times 10^{-4} \mathrm{watt} / \mathrm{cm}^{2}$. Nilai iluminasi cahaya pada setiap posisi pengukuran dapat dilihat pada Tabel 1 dan Gambar 4. 
Tabel 1 Hasil pengukuran Intensitas Sebaran Cahaya Lampu LED 60 watt yang sudah diolah dengan aplikasi surfer 10 (32-bit).

\begin{tabular}{ccccc}
\hline \multirow{2}{*}{ Posisi } & \multicolumn{2}{c}{ Tertinggi } & \multicolumn{2}{c}{ Terendah } \\
& Iluminasi (watt/cm $\left.{ }^{2}\right)$ & Kedalaman $(\mathrm{m})$ & Iluminasi $\left(\right.$ watt $\left./ \mathrm{cm}^{2}\right)$ & Kedalaman $(\mathrm{m})$ \\
\hline 0 & $2,59 \times 10^{-4}$ & 1 & $0,03 \times 10^{-4}$ & 5 \\
1 & $0,08 \times 10^{-4}$ & 1 & $0,01 \times 10^{-4}$ & 9 \\
2 & $0,04 \times 10^{-4}$ & 4 & $0,04 \times 10^{-4}$ & 4 \\
-1 & $0,71 \times 10^{-4}$ & 4 & $0,33 \times 10^{-4}$ & 6 \\
-2 & $0,04 \times 10^{-4}$ & 4 & $0,02 \times 10^{-4}$ & 6 \\
\hline
\end{tabular}

Iluminasi cahaya di dalam air akan berkurang secara eksponensial dengan semakin bertambahnya kedalaman (Gambar 4). Nilai iluminasi cahaya dari titik 0 meter berkurang hingga kedalaman 13 meter. Hal ini pola iluminasi cahaya bergantung dari jarak sumber cahaya, sudut, dan keadaan gelombang Sulaiman et al., (2015).

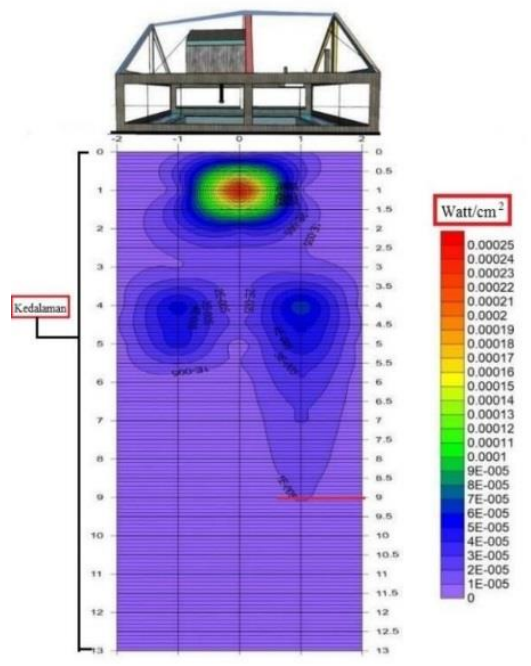

Gambar 4 Distribusi intensitas cahaya lampu LED 60 watt pada bagan rakit.

Gambar 4 menunjukkan intensitas yang berbeda pada kedalaman 3 sampai 9 meter, sehingga terlihat menjadi dua bagian. Hal ini dikarenakan terjadinya pembiasan, adanya partikel dalam air dan kerapatan air. Beberapa faktor lingkungan yang dapat mempengaruhi perbedaan intensitas seperti absorbsi cahaya oleh partikel-partikel terlarut dalam air, panjang gelombang cahaya, kecerahan air dan pemantulan cahaya (Syafrie 2012).

\section{Iluminasi dan Sebaran Cahaya Lampu TL 390 watt dan 585 watt di Lapangan}

Pengukuran iluminasi cahaya yang didapatkan dari hasil pengukuran lampu TL 390 dan 585 watt, cahaya menyebar hingga ke kedalaman 13 meter. Pengukuran lampu TL 390 watt di tengah bagan rakit didapatkan nilai tertinggi pada titik 0 kedalaman 0 meter dengan nilai 0,358 $\mathrm{watt} / \mathrm{cm}^{2}$ sedangkan nilai terendah pada titik 2 kedalaman 12 meter dengan nilai 5,2 x 10-4 watt/ $\mathrm{cm}^{2}$ dengan kecerahan 710 meter. Hasil distribusi iluminasi cahaya lampu TL 390 watt di bagan rakit dengan kecerahan cahaya terlihat sampai kedalaman 4 meter pada titik -1 dengan nilai 0,0193 watt $/ \mathrm{cm}^{2}$. Pada titik 0 kedalaman 0 meter terlihat bahwa warna merah pada gambar 5 tersebut merupakan cahaya yang paling terang, dengan nilai iluminasi tertinggi sebesar 0,358 watt $/ \mathrm{cm}^{2}$. Nilai iluminasi cahaya pada setiap posisi pengukuran dapat dilihat pada Tabel 2 dan Gambar 5. 
Sementara pada pengukuran lampu TL 585 nilai iluminasi tertinggi pada titik 0 kedalaman 1 meter dengan nilai 0,819 watt $/ \mathrm{cm}^{2}$, sedangkan nilai terendah pada titik -2 kedalaman 13 meter dengan nilai 0.0014 watt $/ \mathrm{cm}^{2}$ dengan kecerahan 7-10 meter. Iluminasi cahaya lampu TL 585 watt di bagan rakit dengan kecerahan cahaya dapat terlihat sampai kedalaman 3 meter pada titik 0 dengan nilai 0,0495 watt $/ \mathrm{cm}^{2}$. Pada titik 0 kedalaman 0 meter terlihat warna merah yang mencolok pada gambar 5 merupakan cahaya yang paling terang, dengan nilai iluminasi tertinggi sebesar $0,819 \mathrm{watt} / \mathrm{cm}^{2}$. Nilai iluminasi cahaya pada setiap posisi pengukuran dapat dilihat pada Tabel 2 dan Gambar 5.

Tabel 2 Hasil pengukuran Intensitas Sebaran Cahaya Lampu TL 390 watt dan 585 watt.

\begin{tabular}{ccccccccc}
\hline & \multicolumn{4}{c}{ TL 390} & \multicolumn{3}{c}{ TL 585} \\
Posisi & \multicolumn{2}{c}{ Tertinggi } & \multicolumn{2}{c}{ Terendah } & \multicolumn{2}{c}{ Tertinggi } & \multicolumn{2}{c}{ Terendah } \\
& $\left(\mathrm{watt} / \mathrm{cm}^{2}\right)$ & $(\mathrm{m})$ & $\left(\mathrm{watt} / \mathrm{cm}^{2}\right)$ & $(\mathrm{m})$ & $\left(\mathrm{watt} / \mathrm{cm}^{2}\right)$ & $(\mathrm{m})$ & $\left(\mathrm{watt} / \mathrm{cm}^{2}\right)$ & $(\mathrm{m})$ \\
\hline 0 & 0,3576 & 0 & 0,0206 & 3 & 0,8191 & 0 & 0,0495 & 3 \\
1 & 0,0248 & 1 & 0,0178 & 2 & 0,0359 & 1 & 0,0219 & 0 \\
2 & - & - & - & - & - & - & - & - \\
-1 & 0,0532 & 1 & 0,0193 & 4 & 0,0787 & 1 & 0,0346 & 0 \\
-2 & - & - & - & - & - & - & - & - \\
\hline
\end{tabular}

Keterangan: (-) tidak ada nilai

Iluminasi cahaya sangat bergantung pada jenis sumber cahaya dan jarak antara sumber cahaya dengan bidang permukaan. Iluminasi suatu cahaya akan semakin berkurang dengan bertambahnya kedalaman dan medium air (Ben-Yami 1987). Penetrasi cahaya lampu TL 390 dan 585 watt hanya mampu menembus air hingga kedalaman 3-4 meter dikarenakan adanya perbedaan kecerahan air. Ilustrasi pengukuran iluminasi cahaya lampu TL 390 dan 585 watt dapat dilihat pada Gambar 5.

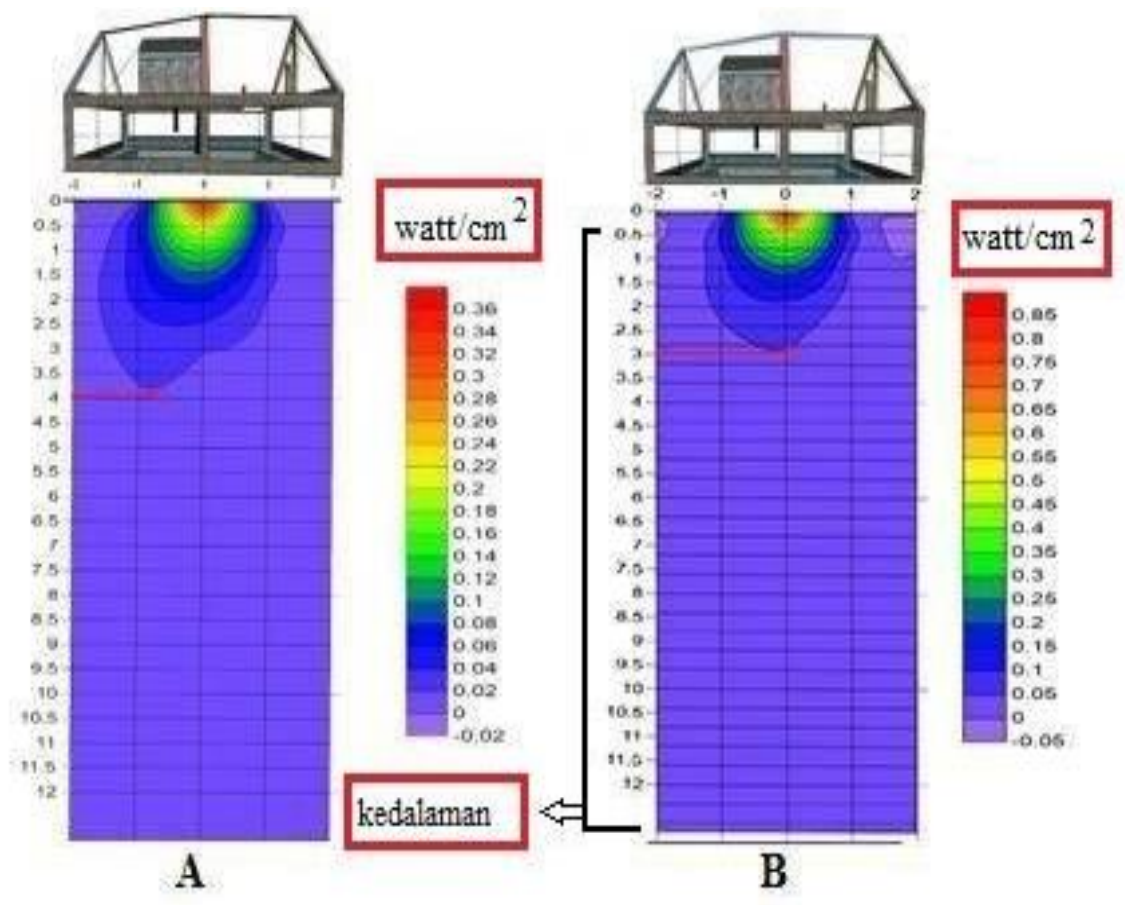

Gambar 5 Distribusi intensitas dan penetrasi cahaya lampu TL 390 watt(A) dan 585 watt(B) di bagan.

Berdasarkan hasil pengukuran lampu TL dengan daya yang berbeda, menunjukkan kemampuan penetrasi cahaya dari masing-masing lampu TL berada pada kedalaman yang sama, yaitu 4 meter, iluminasi cahaya di dalam air akan berkurang secara eksponensial dengan semakin bertambahnya kedalaman (Sulaiman et al., 2015). Intensitas cahaya yang diharapkan dari kedua lampu TL tersebut adalah lampu TL 585 watt yang memiliki daya paling tinggi adalah lampu yang dapat menembus air 
paling jauh hingga kedalaman tertentu melebihi TL 390 watt. Jarak tembus lampu TL 390 watt adalah 4 meter, sedangkan TL 585 watt adalah 3,5 meter. Seharusnya TL 585 watt mampu melampaui jarak penetrasi lampu TL 390 watt. Hal ini disebabkan oleh beberapa faktor yaitu cuaca, kecerahan perairan dan arus pada saat pengoperasian bagan. Nilai iluminasi cahaya dari titik 0 meter berkurang hingga kedalaman 13 meter. Hal ini berkorelasi dengan jarak dari sumber cahaya, gelombang dan medium air yang akan mengurangi iluminasi cahaya (Ben Yami 1987; Syafrie 2012; Sulaiman et al (2015) )

\section{Hasil Tangkapan dengan Lampu LED 60 watt}

Hasil tangkapan dominan bagan yang menggunakan lampu LED 60 watt sebanyak 512,6 kg terdiri lima jenis ikan, yaitu petek (Leiognathus dussumieri) mendominasi hasil tangkapan yaitu sebesar 483,2 kg (94\%). Selain itu selar (Selaroides leptolepis) 18,2 kg, layur (Trichiurus sp.) 6,5 kg, kembung (Rastrelliger sp.) 1,5 kg dan cumi-cumi (Loligo sp.) 3,2 kg.

\section{Hasil Tangkapan dengan Lampu TL 390 watt}

Hasil tangkapan bagan dengan lampu TL 390 watt berjumlah 53,6 kg yang didominasi oleh teri (Stolephorus sp.) yaitu sebanyak 29,5 kg (55\%) selain itu kembung (Rastrelliger sp.) $6 \mathrm{~kg}$, cumi (Loligo sp.) $1 \mathrm{~kg}$, tongkol (Euthynnus affinis) 6,2 kg, bentong (Crumenophthalmus sp.) 2,9 kg dan tembang (Sardinella gibbosa) $8 \mathrm{~kg}$.

\section{Hasil Tangkapan Bagan dengan lampu TL 585 watt}

Hasil tangkapan bagan dengan lampu TL 585 watt berjumlah 95,85 kg yang terdiri dari teri (Stolephorus sp.) mendominasi hasil tangkapan sebesar 46,5 kg (49\%). Jenis ikan lain nya, yaitu petek (Leiognathus dussumierı) $12.5 \mathrm{~kg}$, kembung (Rastrelliger sp.) 4,5 kg, cumi-cumi (Loligo sp.) $10.7 \mathrm{~kg}$, tongkol (Euthynnus affinis) 5,5 kg, tembang (Sardinella gibbosa) 15,7 kg, bentong (Crumenophthalmus sp.) $0,35 \mathrm{~kg}$, dan layur (Trichiurus sp.) $0,1 \mathrm{~kg}$.

Ikan teri menjadi hasil tangkapan dominan dengan menggunakan lampu TL 390 watt dan TL 585 watt sedangkan lampu TL 585 didominasi oleh ikan petek. Jenis ikan yang tertangkap termasuk ikan pelagis yang bersifat fototaksis positif (Taufiq 2015). Ikan teri (Stolephorus sp.) dan pepetek (Leiognathus dussumieri) merupakan hasil tangkapan utama bagan (Subani dan Barus 1988). Hal ini berhubungan dengan keberadaan plankton di bawah lampu bagan yang tangkapan menjadi makanan kedua jenis ikan tersebut (Hutomo et al. 1987). Teri (Stolephorus sp.) merupakan konsumen tingkat trofik pertama dalam rantai makanan (Julian 2014). Hal ini menunjukkan bahwa ikan yang dominan tertangkap adalah ikan teri (Stolephorus sp.) pada lampu TL, dikarenakan jarak penetrasi lampu hanya mencapai 4 meter adalah ikan pelagis kecil yang bersifat fototaksis positif, dimana ruaya ikan teri berada dikisaran kedalaman 1 hingga 4 meter sesuai yang ditulis Taufiq (2015). Hal ini disebabkan oleh sebaran intensitas cahaya lampu LED dan TL dalam air dapat menyebar hingga kedalaman 13 meter. Nilai sebaran intensitas cahaya kedua lampu ini akan semakin menurun seiring dengan meningkatnya kedalaman perairan yang dipengaruhi oleh absorbsi cahaya oleh partikel-partikel terlarut dalam air, panjang gelombang cahaya, kecerahan air, pemantulan cahaya, serta musim dan lintang geografis (Syafrie 2012).

\section{KESIMPULAN}

Penetrasi cahaya lampu LED 60 mampu menembus perairan hingga kedalaman 9 meter pada kecerahan 7-10 meter. Lampu TL 390 watt mencapai kedalaman 4 meter, dan TL 585 hanya 3 meter. Nilai iluminasi cahaya tertinggi lampu LED 60 watt terdapat pada titik 0 kedalaman 1 meter dengan nilai $2,5 \times 10^{-4}$ watt $/ \mathrm{cm}^{2}$ dan terendah terdapat pada titik 2 kedalaman 13 meter dengan nilai $0,003 \times 10^{-}$ ${ }^{4}$ watt $/ \mathrm{cm}^{2}$. Nilai iluminasi cahaya lampu TL 390 watt tertinggi yaitu terjadi pada titik 0 pada kedalaman 0 meter dengan nilai 0,358 watt $/ \mathrm{cm}^{2}$ dan nilai terendah terjadi pada titik 2 dikedalaman 12 meter dengan nilai $5 \times 10^{-4} \mathrm{watt} / \mathrm{cm}^{2}$. Nilai iluminasi cahaya lampu TL 585 watt tertinggi yaitu terjadi pada 
titik 0 pada kedalaman 0 meter dengan nilai 0,819 watt $/ \mathrm{cm}^{2}$ dan nilai terendah terjadi pada titik -2 dikedalaman 13 meter dengan nilai 0,0014 watt $/ \mathrm{cm}^{2}$. Hasil tangkapan LED dalam didominasi oleh ikan petek sebesar 94\%, lampu TL 390 dan TL 585 watt didominasi ikan teri (Stolephorus sp.) sebesar 55\% dan $49 \%$.

\section{DAFTAR PUSTAKA}

Ahmad S, Puspito G, Sondita FA, dan Yusfiandayani R. 2013. Penguatan Cahaya pada bagan Menggunakan Reflektor Kerucut Sebagai Upaya meningkatkan Hasil Tangkapan Cumi-Cumi. Jurnal Marine Fisheries, Vol 4 No 2.

Ben-Yami M. 1987. Fishing with Light. Surrey (GB): Arrangement with FAO of The United Nations by fishing News Books

[BBPPI] Balai Besar Pengembangan Penangkapan Ikan. 2007. Klasifikasi Alat Penangkapan Ikan Indonesia. Jakarta (ID): [BBPPI] Balai Besar Pengembangan Penangkapan Ikan.

Haruna. 2010. Distribusi cahaya lampu dan tingkah laku ikan pada proses penangkapan bagan perahu di perairan Maluku Tengah. Jurnal Amanisal. 1(1): 22-29.

Hasan. 2008. Uji Coba Penggunaan Lampu Latjuba Tenaga Surya pada Bagan Apung terhadap Hasil Tangkapan di Palabuhanratu, Jawa Barat. Jurnal Sains dan Teknologi. 2(3): 11-18.

Holil U. 2000. Studi tentang sebaran cahaya lampu TL dalam air dengan sumber solar cell system pada pengoperasian bagan apung [skripsi]. Bogor (ID): Institut Pertanian Bogor.

Hutomo M, Burhanuddin A, Djamali S. Martosewojo. 1987. Sumberdaya Ikan Teri (Stholeporus sp.) di Indonesia. Jakarta (ID): Proyek Studi Sumberdaya Laut. Pusat Penelitian dan Pengembangan Oseanologi-LIPI.

Julian D. 2014. Uji coba penangkapan ikan dengan bagan tancap menggunakan lampu LED (Light Emitting Diode) [skripsi]. Bogor (ID): Intitut Pertanian Bogor.

Patty W. 2010. Analisis Sebaran Iluminasi Cahaya Petromaks dengan Perlakuan Bertudung dan Tanpa Tudung. Jurnal Perikanan dan Kelautan. 6 (3). 156-159.

Puspito G. 2008. Uji Coba Penggunaan Tudung Petromaks Berbentuk Kerucut pada Bagan Apung. Jurnal Mangrove dan Pesisir. 8 (1): hal 1-11.

Puspito G. 2012. Pengaruh pemusatan cahaya terhadap evektivitas bagan. Jurnal Saintek Perikanan. 7 (2): 5-9.

Rifaldi A. 2016. Respon tingkah laku ikan terhadap lampu LED (Light Emitting Diode) bawah air pada bagan apung [skripsi]. Bogor (ID): Intitut Pertanian Bogor.

Setiawan F, Sulistiyanti S, Sadnowo A. 2015. Analisis Pengaruh Medium Perambatan Intensitas Cahaya. Jurnal Rekayasa dan Teknologi Elektro. 6(2) 49-54.

Subani W, Barus HR. 1988. Alat penangkapan ikan dan udang di Indonesia. Nomor 50 tahun 1989/1999 edisi khusus. Jurnal Penelitian Perikanan Laut. Jakarta (ID): Balai Penelitian Perikanan Laut.

Suuronen P, Chopin F, Glass C, Lokkeborg S, Matsushita Y, Queirolo D, and Rihan D. 2012. Low impact and fuel effecient fishing. Journal. home page: www.elsevier.com / locate / fishres.

Sulaiman M, Baskoro MS, Yusfiandayani R, Taurusman AA, dan Wisudo SH. 2015. Tingkah laku ikan pada perikanan bagan pete-pete yang menggunakan lampu LED. Jurnal Ilmu dan Teknologi Kelautan Tropis. 7(1): 205-223. 
Syafrie H. 2012. Efektivitas lampu tabung pada perikanan bagan [tesis]. Bogor (ID): Institut Pertanian Bogor.

Taufiq. 2015. Pengembangan lampu celup LED (Super Bright Blue) untuk perikanan bagan apung di perairan Patek kabupaten Aceh Jaya [tesis]. Bogor (ID): Institut Pertanian Bogor. 